\title{
NOSITELÉ NOBELOVY CENY ZA EKONOMII PRO ROK 2011
}

Pavel Sirůček, Vysoká škola ekonomická v Praze

V roce 2011 získali tzv. Nobelovu cenu za ekonomii tradičně další Američané T. J. Sargent (*1943) a Ch. A. Sims (*1942), a to za ,empirický výzkum príčin a di̊sledků $v$ makroekonomii “. Z dosavadních šedesáti devíti laureátů (z toho jedna žena) této Nobelovy ceny (NC) jsou USA jako domovská země uváděny, resp. spoluuváděny, u plných padesáti.

Sargent a Sims prováděli výzkumy nezávisle na sobě zejména v 70. a 80. letech, jejich výsledky se přitom v mnohém doplňují. Ocenění získali za zkoumání př́icinných vztahů mezi změnami hospodářské politiky a změnami makroproměnných, především v kontextu teorie racionálních očekávání. Jejich metody, které dnes náleží k základním nástrojům makroanalýz, napomáhají vysvětlit, jak rozhodnutí vlád a centrálních bank ovlivňují růst, nezaměstnanost, inflaci nebo investice. Přispívají též k pochopení dopadů hospodářských změn či šoků.

Poukazováno je na aktuálnost prací oceněných v době globálních krizí a recesí, včetně hledání východisek z krize dluhové. Oba autoři jsou vlivní v oblasti teorie i hospodářské praxe a politiky. Názory a koncepce obou byly integrovány do hlavních proudů ekonomické vědy. Především Sargent, spojený s reaganovskou ekonomikou, přitom nepatří ke keynesovsky orientovaným ekonomům a oba nepodporují přehnané intervence do ekonomiky. Rovněž nevěří v pozitivní efekty rozsáhlých fiskálních injekcí v časech krize. Sims se vyjadřuje též k aktuálním problémům Eurozóny a doporučuje vytvoření fiskální unie pro zabránění kolapsu jednotné měny. Vratké fiskální základy evropské integrace kritizuje již dlouhodobě.

\section{THOMAS JOHN SARGENT}

Americký ekonom a ekonometr (New York University, New York) náleží k čelným reprezentantům nové klasické makroekonomie. Zabývá se makroekonomií a monetární ekonomií, s důrazem na úlohu očekávání v makromodelech a vztahy mezi dynamickou ekonomickou teorií a ekonometrií časových řad. Vyzdvihován bývá jeho metodologický př́nos $\mathrm{k}$ empirickému výzkumu strukturálních makromodelů a racionálních očekávání. Tradiční přednášku při příležitosti udělení NC proslovil na téma „,United States Then, Europe Now" 8. 12. 2011.

Sargent je spoluzakladatelem nové klasické makroekonomie I založené na konceptu racionálních očekávání. Jedná se o aplikaci principu racionálního maximalizačního chování v oblasti získávání a využívání informací v procesu formování představ o budoucnosti. Vedle hypotézy racionálních očekávání patří $\mathrm{k}$ centrálním 
piliřům nové klasické makroekonomie představa efektivních vyčištujících se trhů. Označení nová klasická makroekonomie I je používáno pro koncepce vycházející především z díla R. E. Lucase (oceněného NC v roce 1995). Modely operují s hypotézou racionálních očekávání v dynamických modelech celkové ekonomické rovnováhy a s dokonale pružnou cenovou tvorbou.

Sargent přispěl k vybudování ekonometrických základů nové klasické makroekonomie i k definitivnímu rozpadu tradiční „velké neoklasické syntézy“. Striktní interpretace modelů nové klasické makroekonomie již neposkytují žádný prostor pro syntézu s neokeynesovstvím. Sargentovy studie se setkaly i s odporem a v kontextu antikeynesovské revoluce bývá řazen k tzv. „čtyřem jezdcům Apokalypsy“ (vedle R. E. Lucase, R. J. Barra a E. Ch. Prescotta).

K zakladatelským počinům při formování školy racionálních očekávání náleží též Sargentova stat' „A Note on the „Accelerationist“ Controversy“ (1971). V textech z počátku 70. let empiricky testuje teorie založené na předpokladu existence rovnovážné přirozené míry nezaměstnanosti a na tom, že všechny odchylky od ní jsou náhodné. Tyto se systematicky nevztahují k žádné relevantní ekonomické proměnné proto, že očekávání jsou racionální a subjekty zohledňují i pravidla a důsledky politik. Pokud subjekty adekvátně předpovídají všechny cenové aj. změny, pak vládní politiky mohou ovlivnit pouze nominální proměnné.

Na základě Lucasova díla formuluje Sargent, spolu s N. Wallacem, tezi o neúčinnosti hospodářské politiky (1975). Jde o ekonometrický model, v němž subjekty jsou schopny racionálně předvídat důsledky systematických politik a předem se jim prrizpůsobovat. Subjekty na úrovni celé ekonomiky jsou schopny, př̀ dostatku času na zpracování relevantních informací, vytvářet správná očekávání budoucího vývoje a adekvátně přizpůsobovat svá chování a strategie. Predikovatelná opatření jsou tedy neúčinná a systematická hospodářská politika se míjí účinkem. Reálné dopady mají pouze překvapení, resp. šoky, které ovšem ekonomiku obvykle spíše destabilizují. Za nejlepší hospodářskou politiku tudíž nová klasická makroekonomie považuje dlouhodobá stabilní pravidla.

Sargent je autorem antikeynesovských učebnicových textů (1979 aj.). Společně s Lucasem sepsali v duchu racionálních očekávání esej „After Keynesian Macroeconomics “ (1979). Tu, spolu s dalšími důležitými texty Sargenta aj., obsahuje sborník „,Rational Expectations and Econometric Practice“ “(1981). Sargent s Lucasem kritizují používání rozsáhlých makromodelů $\mathrm{k}$ vyhodnocování účinnosti různých hospodářských opatření. Kritika poukazuje na to, že modely předpokládají neměnnost makrovztahů při změně politiky. Ekonomické chování se ovšem mění v reakci na změnu politiky. Makrovztahy se často mění, což mají dokazovat špatné výsledky prognostických modelů (které selhaly např. u stagflace 70 . let).

Jeho práce ukazují, jak může být strukturální a empirická makroekonometrie využita $\mathrm{k}$ analýze trvalých změn a vlivů hospodářských politik. Sargentovy metody lze použít i při studiu makrovztahů, kdy domácnosti a firmy přizpůsobují svá očekávání současnému vývoji. 
Ve výzkumech se Sargent často zabýval poválečnou érou tlaků na vysokou inflaci. Zkoumal velké inflace a hyperinflace v minulosti a tvrdil (1982 aj.), že velké evropské inflace končily díky důvěryhodným reformám monetární a fiskální politiky rychle a při nízkých nákladech. A usuzoval, že USA (v časech dvojciferné inflace) by měly reagovat obdobně. Věnuje se i problémům spadajících do historické ekonomie atd. S N. Wallacem propočítávají důsledky vládního rozpočtového omezení, kdy dluhové financování deficitu může mít v dlouhém období větší inflační účinky než peněžní financování (1981).

Sargent se narodil 19. 7. 1943 v kalifornské Pasadeně. Bakalářská studia absolvoval na University of California v Berkeley (B.A. - 1964), doktorát obdržel na Harvard University (Ph.D. - 1968). Po důstojnické službě v armádě (1968-69) vyučoval ekonomii na University of Pennsylvania (1970-71). Dále pracoval na University of Minnesota jako docent (1971-75), resp. profesor ekonomie (1975-87). Spolupracuje s National Bureau of Economic Research (1970-73 a od roku 1979 dosud), s Hoover Institution při Stanford University (1985-87, resp. od roku 1987), konzultoval s Federal Reserve Bank of Minneapolis (1971-87), hostoval na University of Chicago (1976-77), Harvard University (1981-82), Princeton University (2009). Na University of Chicago zastával pozici profesora ekonomie v letech 1992-98, na Stanford University byl profesorem ekonomie v období 1998-2002.

Od roku 2002 působí jako profesor ekonomie a podnikání na New York University. Je držitelem několika ocenění a čestných doktorátů. Byl činný v redakcích odborných periodik. Je členem Econometric Society, American Economic Association, Society for Economic Dynamics či National Academy of Sciences a American Academy of Arts and Sciences.

\section{Hlavní knižní publikace:}

Macroeconomics Theory (Academic Press, 1979, 1987); Rational Expectations and Econometric Practice ((eds.), Vol. 1, 2, University of Minnesota Press, 1981 - spolueditor R. E. Lucas); Energy, Foresight and Strategy ((ed.), Resources for the Future, 1985); Rational Expectations and Inflation (Harper \& Row, 1986); Dynamic Macroeconomic Theory (Harvard University Press, 1987); Exercises in Dynamic Macroeconomic Theory (Harvard University Press, 1987 - společně s R. E. Manuellim); Rational Expectations Econometrics (Westviev Press, 1991 - spolu s L. P. Hansenem); Bounded Rationality in Macroeconomics: The Arne Ryde Memorial Lectures (Oxford University Press, 1993); The Conquest of American Inflation (Princeton University Press, 1999); Recursive Macroeconomic Theory (MIT Press, 2000, 2004 - spoluautor L. Ljungqvist); The Big Problem of Small Change (Princeton University Press, 2002 - společně s F. R. Veldem); Robustness (Princeton University Press, 2008 - spolu s L. P. Hansenem).

\section{Klíčové stati a časopisecké příspěvky:}

Commodity Price Expectations and the Interest Rate (Quarterly Journal of Economics, February 1969); A Note on the "Accelerationist" Controversy (Journal of Money, 
Credit and Banking, August 1971); The Stability of Models of Money and Growth with Perfect Foresight (Econometrica, November 1973 - společně s N. Wallacem); Rational Expectations and the Dynamics of Hyperinflation (International Economic Review, June 1973 - spolu s N. Wallacem); The Elasticity of Substitution and Cyclical Behavior of Productivity, Wages and Labor's Share (American Economic Review, May 1974 - společně s N. Wallacem); ,Rational“" Expectations, the Optimal Monetary Instrument, and the Optimal Money Supply Rule (Journal of Political Economy, April 1975 - spoluautor N. Wallace); A Classical Macroeconometric Model for the United States (Journal of Political Economy, April 1976); Rational Expectations and the Theory of Economic Policy (Journal of Monetary Economics, April 1976 - spolu s N. Wallacem); Business Cycle Modeling without Much A Priori Economic Theory (in Sims, Ch. A. (ed.): New Methods in Business Cycle Research, Federal Reserve Bank of Minneapolis, 1977 - společně s Ch. A. Simsem); After Keynesian Macroeconomics (Quarterly Review, Federal Reserve Bank of Minneapolis, Spring 1979 - spolu s R. E. Lucasem); Formulating and Estimating Dynamic Linear Rational Expectations Models (Journal of Economic Dynamics and Control, February 1980 - společně s L. P. Hansenem); Rational Expectations and the Reconstruction of Macroeconomics (Quarterly Review, Federal Reserve Bank of Minneapolis, Summer 1980); Interpreting Economic Time Series (Journal of Political Economy, April 1981); Some Unpleasant Monetarist Aritmetic (Federal Reserve Bank of Minnesota Quarterly Review, Autumn 1981 - spolu s N. Wallacem); The Ends of Four Big Inflations (in Hall, R. E. (ed.): Inflation: Causes and Effects, University of Chicago Press, 1982); The Real-Bills Doctrine Versus the Quantity Theory: A Reconsideration (Journal of Political Economy, December 1982 - společně s N. Wallacem); Autoregressions, Expectations, and Advice (American Economic Review, May 1984); Interest on Reserves (Journal of Monetary Economics, May 1985 - spolu s N. Wallacem); Convergence of Least Squares Learning Mechanism in Self-Referential Linear Stochastic Models (Journal of Economic Theory, August 1989 - společně s A. Marcetem); Two Models of Masurements and the Ivestment Acelerator (Journal of Political Economy, April 1989); Macroeconomic Features of the French Revolution (Journal of Political Economy, June 1995 - spolu s F. R. Veldem); Welfare States and Unemployment (Economic Theory, June 1995 - společně s L. Ljungqvistem); A Supply-Side Explanation of European Unemployment (Economic Perspectives, September 1996 - spolu s L. Ljungqvistem); A Primer on Monetary and Fiscal Policy (Journal of Banking \& Finance, October 1999); Robust Control and Model Uncertainty (American Economic Review, May 2001 - společně s L. P. Hansenem); Robust Control of Forward-Looking Models (Journal of Monetary Economics, April 2003 - spolu s L. P. Hansenem); Understanding European Unemployment with a Representative Family Model (Journal of Monetary Economics, November 2007 společně s L. Ljungqvistem); Alternative Monetary Policies in a Turnpike Economy (Macroeconomic Dynamics, November 2010 - spolu s R. E. Manuellim); A Labor Supply Elasticity Accord? (American Economic Review, May 2011 - společně s L. Ljungqvistem); Two Illustrations of the Quantity Theory of Money: Breakdowns and Revivals (American Economic Review, February 2011 - spoluautor P. Surico). 


\section{Doplňující informace:}

After the Phillips Curve: Persistence of High Inflation and High Unemployment (Lucas, R. E., Sargent, T. J., Federal Reserve Bank of Boston, 1978); Rational Expectations and Economic Policy (Fisher, S. (ed.), University of Chicago Press, 1980); Rational Expectations (Sheffrin, S. M., Cambridge University Press, 1983); též viz https://files.nyu.edu/ts43/public.

\section{CHRISTOPHER ALBERT SIMS}

Americký ekonom a ekonometr (Princeton University, Princeton), který se zaměřuje na ekonometrické teorie $\mathrm{v}$ oblasti dynamických modelů a na makroteorii a politiku. V kontextu empirické makroekonomie propracoval metody vektorových autoregresí, podílel se na fiskální teorii cenové hladiny, teorii racionální nepozornosti aj. Bývá též řazen k novým klasickým makroekonomům, ale má blížeji k nové keynesovské ekonomii než liberálněji orientovaný T. J. Sargent vyznávající principy volného trhu. Simsova přednáška při udělení NC dne 8. 12. 2011 nesla název „Statistical Modeling of Monetary Policy and its Effects".

Vědecko-výzkumné aktivity Simse jsou orientovány především na ekonometrii a jeho dílo je blízké matematice a statistice. Je oceňován za spojení matematických a statistických metod $\mathrm{s}$ reálnou ekonomikou. Př́stupy racionálních očekávání T. J. Sargenta doplňuje Sims o ekonometrické instrumentarium, v čele s metodami vektorové autoregrese (1980 aj.). Tyto využívá ke studiu př́čin a následků mezi makrojevy a proměnnými. Analyzovány jsou dopady různých hospodářských politik (např. změn úrokových či daňových sazeb).

Vektorové autoregresní modely (VAR) operují s tím, že vysvětlovaná veličina je závislá i na svém předchozím chování. Technicistní vysvětlení chování makroveličin nevyžaduje detailní popis chování a reakcí všech aktérů. VAR modely na ekonomických datech umožňují rozpoznat, jak ekonomika reagovala na vnější impuls i to, co z jejího chování je možné připsat jiným příčinám. Metody Simse napomáhají též $\mathrm{k}$ identifikacím a kvalitnějším odhadům dopadů různých ekonomických šoků, pomáhají lépe předvídat i cílovat inflaci, mohou být využity pro identifikaci širších vztahů mezi ekonomikou a politikou atd.

Sargent a Sims ukazují, že prŕčiny a následky mezi makrojevy a veličinami je možné analyzovat pomocí historických dat, navzdory vzájemnému ovlivňování makroveličin. Sargent se v tomto kontextu soustředí na využití dat k analýze vlivu systematických změn hospodářských politik a pravidel na ekonomiku v čase. Sims věnuje pozornost rozlišení očekávaných a neočekávaných změn veličin (napřr. úrokových měr, cen ropy) ke zjišstování př́slušných dopadů na klíčové makroukazatele. 
Ch. A. Sims je jedním z duchovních otců fiskální teorie cenové hladiny (1994). Podle této inflaci ovlivňuje nejen politika monetární, ale i fiskální mající prrímé dopady na tvorbu cen. Např. velké dluhy zemí působí na inflaci a inflace se chová jinak, než postulují mnohé tradiční koncepce. A vyrovnaný rozpočet může přispívat ke stabilnímu vývoji inflace.

Obdobně jako u Sargenta bývá vyzdvihován teoretický i metodologický př́nos Simsových výzkumů potvrzujících význam koncepce racionálních očekávání, resp. předpokladu racionality v ekonomické vědě. Sims pokládá základy teorie racionální nepozornosti (2003). Koncept spočívá na předpokladu, že pro běžné ekonomické subjekty je nákladné získávat a zpracovávat všechny informace, zejména díky časové náročnosti a obtížnosti vyznat se $\mathrm{v}$ nich. Proto svá rozhodnutí a chování nemění plynule, nýbrž skokovitě. Existuje tendence ke zjednodušování informací a rozhodování bez jejich detailní znalosti. Což může vést $\mathrm{k}$ problémům na trzích, $\mathrm{k}$ finanční nákaze (kdy na základě povrchních znalostí investoři hromadně nakupují dluhopisy různých zemí nebo je naopak zase všechny prodávají) apod. V oblasti teorie racionální nepozornosti se Simsem spolupracuje F. Matějka.

Sims se narodil 21. 10. 1942 ve Washingtonu. B.A. v matematice obdržel na Harvard College (1963), dále studuje na University of California v Berkeley (1963-64). Ekonomický doktorát (Ph.D.) získává na Harvard University s disertací ",The Dynamics of Productivity Change: A Theoretical and Empirical Study“ (1968). Vyučuje ekonomii na Harvard University (1967-68) a působí zde i coby docent (1968-70). V letech 1970-74 je docentem a v období 1974-90 profesorem ekonomie na University of Minnesota; $v$ letech 1990-99 zastává pozici profesora ekonomie na Yale University. Od roku 1999 působí na Princeton University jako profesor ekonomie, resp. od roku 2004 jako profesor ekonomie a bankovnictví.

Zúčastnil se výzkumů National Bureau of Economic Research (1970-71); hostoval na Yale University (1974), na Massachusetts Institute of Technology (1979-80); konzultoval s Federal Reserve Bank of Minneapolis (1983, 1986-87) či Federal National Mortgage Association (1999-2002); působil jako ředitel Institute for Empirical Macroeconomics v Minneapolis (1987-91); spolupracoval s Federal Reserve Bank of Atlanta (1995), of New York (1994-97 a od roku 2004), of Philadelphia (2000-03), s International Monetary Fund apod.; spolueditoval časopis Econometrica (1977-81) a působí v redakčních radách dalších prestižních tiskovin. Je členem American Academy of Arts and Sciences, National Academy of Sciences, zastával funkci prezidenta Econometric Society (1995), v roce 2011 byl jmenován prezidentem American Economic Association atd.

\section{Hlavní knižní publikace:}

New Methods in Business Cycle Research ((ed.), Federal Reserve Bank of Minneapolis, 1977); Advances in Econometrics: Sixth World Congress ((ed.), Vol. 1, 2, Cambridge University Press, 1994). 


\section{Klíčové stati a časopisecké příspěvky:}

Evaluating Short-Term Macroeconomics Forecasts: The Dutch Experience (Review of Economics and Statistics, May 1967); Theoretical Basis for a Double Deflated Index of Real Value Added (Review of Economics and Statistics, November 1969); Discrete Approximations to Continuous Time Distributed Lags in Econometrics (Econometrica, May 1971); Distributed Lag Estimation when the Parameter Space is Explicitly InfiniteDimensional (Annals of Mathematical Statistics, October 1971); Money, Income and Causality (American Economic Review, September 1972); Seasonality in Regression (Journal of American Statistical Association, September 1974); Comparison of Interwar and Postwar Business Cycles: Monetarism Reconsidered (American Economic Review, May 1980); Macroeconomics and Reality (Econometrica, January 1980); Is There a Monetary Business Cycle? (American Economic Review, May 1983); Nearly Efficient Estimation of Time Series Models with Predetermined, but not Exogenous, Istruments (Econometrica, May 1983 - spoluautor F. Hayashi); Inference in Linear Time Series Models with Some Unit Roots (Econometrica, January 1990 - společně s J. H. Stockem a M. W. Watsonem); Understanding Unit Rooters: A Helicopter Tour (Econometrica, November 1991 - spoluautor H. D. Uhlig); A Simple Model for Study of the Determination of the Price Level and the Interaction of Monetary and Fiscal Policy (Economic Theory, 4, 1994); Macroeconomics and Methodology (Journal of Economic Perspectives, Winter 1996); Using a Likelihood Perspective to Sharpen Econometric Discource: Three Examples (Journal of Econometrics, April 2000); Fiscal Consequences for Mexico of Adopting the Dollar (Journal of Money, Credit and Banking, May 2001); Implications of Rational Inattention (Journal of Monetary Economics, April 2003); Does Monetary Policy Generate Recessions? (Macroeconomics Dynamics, April 2006 - spoluautor T. Zha); Rational Inattention: Beyond the Linear-Quadratic Case (American Economic Review, May 2006); Were There Regime Switches in us Monetary Policy? (American Economic Review, May 2006 - spoluautor T. Zha); Methods for Inference in Large Multiple-Equation Markov-Switching Models (Journal of Econometrics, October 2008 - spoluautoři D. F. Waggoner a T. Zha); But Economics Is Not an Experimental Science (Journal of Economic Perspectives, Spring 2010); Stepping on a Rake: The Role of Fiscal Policy in the Inflation of the 1970s (European Economic Review, January 2011).

\section{Doplňující informace:}

Business Cycle Modeling without Pretending to Have too Much a Priori Economic Theory (Sargent, T. J., Sims, Ch. A., Federal Reserve Bank of Minneapolis, 1977); Discrete Actions in Information-Constrained Tracking Problems (Matějka, F., Sims, Ch. A., CERGE-EI Working Papers, 2011); též viz http://www.princeton.edu/ sims. 